\title{
Palleronia marisminoris gen. nov., sp. nov., a moderately halophilic, exopolysaccharide- producing bacterium belonging to the 'Alphaproteobacteria', isolated from a saline soil
}

Correspondence Victoria Béjar vbejar@ugr.es

\author{
Fernando Martínez-Checa, Emilia Quesada, M. José Martínez-Cánovas, \\ Inmaculada Llamas and Victoria Béjar
}

\begin{abstract}
Microbial Exopolysaccharide Research Group, Department of Microbiology, Faculty of Pharmacy, Campus Universitario de Cartuja, University of Granada, 18071 Granada, Spain
\end{abstract}

\begin{abstract}
Strain $B 33^{\top}$ is a moderately halophilic, exopolysaccharide-producing, Gram-negative, non-motile rod isolated from a hypersaline soil bordering a saline saltern on the Mediterranean seaboard in Murcia (Spain). The bacterium is chemoheterotrophic and strictly aerobic. It contains a pink pigment but does not synthesize bacteriochlorophyll a. It requires $0.66 \mathrm{M} \mathrm{Na}^{+}, 0.1 \mathrm{M} \mathrm{Mg}^{2+}$ and $0 \cdot 1 \mathrm{M} \mathrm{K}^{+}$for optimum growth. It does not produce acid from carbohydrates. It cannot grow with carbohydrates, organic acids, sugars, alcohols or amino acids as sole sources of carbon and energy. Its major fatty-acids are $18: 1 \omega 7 c(68 \cdot 9 \%)$ and $19: 0$ cyclo $\omega 8 c(12 \cdot 8 \%)$. The sole respiratory lipoquinone found in strain $B 33^{\top}$ is ubiquinone-10. The DNA G $+C$ content is 64.2 mol\%. 16S rRNA gene sequence comparisons show that the isolate is a member of the Roseobacter clade within the class 'Alphaproteobacteria'. The similarity values with Roseivivax halodurans and Roseivivax halotolerans are 88.2 and $88.0 \%$ respectively and $92.2 \%$ with Salipiger mucosus. DNA-DNA hybridization values with these species are $<30 \%$. In the light of the polyphasic evidence gathered in this study it is proposed that the isolate be classified as a novel genus and species with the name Palleronia marisminoris gen. nov., sp. nov. The proposed type strain is strain B33 ${ }^{\top}\left(=\right.$ CECT $7066^{\top}=$ LMG $\left.22959^{\top}\right)$.
\end{abstract}

Moderately halophilic bacteria require from 3 to $15 \% \mathrm{w} / \mathrm{v}$ $\mathrm{NaCl}$ for satisfactory growth (Kushner \& Kamekura, 1988). They are widely distributed among many hypersaline habitats. Taxonomically the majority of Gram-negative halophilic bacteria belong to the class 'Gammaproteobacteria' but they can also be found in other bacterial phyla (Ventosa et al., 1998). Some halophilic micro-organisms, such as those which produce exopolysaccharides (EPS), have interesting industrial applications (Quesada et al., 2004). Microbial EPS have a potentially wide range of applications in such fields as pharmacy, foodstuffs, cosmetics and the petroleum industry, where emulsifying, viscosifying, suspending and chelating agents are required (Sutherland, 1990). During an extensive search of 18 hypersaline habitats in Spain and Morocco, designed to obtain new EPS, we discovered that

Published online ahead of print on 16 September 2005 as DOI 10.1099/ijs.0.63906-0.

Abbreviations: EPS, exopolysaccharide; PHA, poly- $\beta$-hydroxyalkanoate. The GenBank/EMBL/DDBJ accession number for the 16S rRNA gene sequence of Palleronia marisminoris B33 ${ }^{\top}$ is AY926462.

A more detailed phylogenetic tree based on 16S rRNA gene sequences is available as a supplementary figure in IJSEM Online. the commonest halophilic EPS-producers were various species of the genus Halomonas, most importantly Halomonas maura and Halomonas eurihalina (Quesada et al., 1990, 2004; Bouchotroch et al., 2001; Martínez-Cánovas et al., 2004d). As a result of these searches we have described the first moderately halophilic EPS-producing micro-organism belonging to the 'Alphaproteobacteria', Salipiger mucosus (Martínez-Cánovas et al., 2004e), three novel Halomonas species, Halomonas ventosae (Martínez-Cánovas et al., 2004c), Halomonas anticariensis (Martínez-Cánovas et al., 2004a) and Halomonas almeriensis (Martínez-Checa et al., 2005a), two new Idiomarina species, Idiomarina fontislapidosi and Idiomarina ramblicola (Martínez-Cánovas et al., 2004b), and a new Alteromonas species, Alteromonas hispanica (MartínezCheca et al., 2005b), all of which produce EPS. We describe and classify here an unassigned halophilic EPS-producing strain also isolated in these studies and propose it as a novel genus and species belonging to the class 'Alphaproteobacteria' with the name Palleronia marisminoris.

The strain in question, $\mathrm{B} 33^{\mathrm{T}}$, was isolated from a saline soil bordering a saltern on the Mediterranean seaboard at Marchamalo (Murcia, south-eastern Spain) (MartínezCánovas et al., 2004d). It was routinely grown at $32{ }^{\circ} \mathrm{C}$ in MY 
medium (Moraine \& Rogovin, 1966) supplemented with a $5 \% \mathrm{w} / \mathrm{v}$ sea-salt solution (Rodríguez-Valera et al., 1981). Its phenotype was studied with 135 tests by Martínez-Cánovas et al. (2004d) and it was included in phenon E along with other unidentified strains. The procedures we followed for its phenotypic characterization have been described by Ventosa et al. (1982), Quesada et al. (1983) and Mata et al. (2002). Salt requirements and optimum salt concentration were determined in MY medium (Moraine \& Rogovin, 1966). The salt concentrations assayed ranged from 0.5 to $30 \% \mathrm{w} / \mathrm{v}$ and were prepared from a mixture of sea salts according to Rodríguez-Valera et al. (1981). We also tested to see whether strain $\mathrm{B} 33^{\mathrm{T}}$ could survive with $\mathrm{NaCl}$ alone or whether it required other sea salts. To determine its nutritional requirements we also assayed its growth in Koser medium supplemented with yeast extract $(0 \cdot 1-3 \% \mathrm{w} / \mathrm{v})$, malt extract $(1-3 \% \mathrm{w} / \mathrm{v})$ or proteose peptone $(1-5 \% \mathrm{w} / \mathrm{v})$. The presence of bacteriochlorophyll $a$ was analysed spectrophotometrically using the procedure of Cohen-Bazire et al. (1957), following the recommendations of Allgaier et al. (2003). DNA was purified using the technique of Marmur (1961). The $\mathrm{G}+\mathrm{C}$ content of the DNA was estimated from the midpoint value $\left(T_{\mathrm{m}}\right)$ of the thermal denaturation profile (Marmur \& Doty, 1962). $T_{\mathrm{m}}$ was determined by the graphic method described by Ferragut \& Leclerc (1976) and the DNA G $+\mathrm{C}$ content was calculated from this temperature using Owen and Hill's equation (Owen \& Hill, 1979). The $T_{\mathrm{m}}$ value of reference DNA from Escherichia coli NCTC $9001^{\mathrm{T}}$ was taken to be $74 \cdot 6^{\circ} \mathrm{C}$ in $0 \cdot 1 \times$ SSC (Owen \& Pitcher, 1985).

Table 1. Characteristics that distinguish Palleronia marisminoris $B 33^{\top}$ from related members of the family 'Rhodobacteraceae'

Taxa: 1, Palleronia marisminoris $\mathrm{B} 33^{\mathrm{T}}$; 2, Salipiger mucosus CECT $5855^{\mathrm{T}}$ (Martínez-Cánovas et al., 2004e); 2, Roseivivax halodurans JCM $10272^{\mathrm{T}}$; 4, Roseivivax halotolerans JCM $10271^{\mathrm{T}}$ (Suzuki et al., 1999; Nishimura et al., 1994). +, Positive; -, negative; ND, no data available; RT, retention time; S, single; SP, subpolar.

\begin{tabular}{|c|c|c|c|c|}
\hline Characteristic & 1 & 2 & 3 & 4 \\
\hline Source & $\begin{array}{l}\text { Hypersaline } \\
\text { soil }\end{array}$ & $\begin{array}{l}\text { Hypersaline } \\
\text { soil }\end{array}$ & $\begin{array}{l}\text { Charophyte sp. } \\
\text { in a saline lake }\end{array}$ & $\begin{array}{l}\text { Cyanobacterial mat } \\
\text { in a saline lake }\end{array}$ \\
\hline Pigment & Pink & - & Pink & Pink \\
\hline Flagella & - & - & S, SP & S, SP \\
\hline PHA & + & + & ND & ND \\
\hline Oxidase & - & + & + & + \\
\hline EPS production & + & + & - & - \\
\hline Bacteriochlorophyll $a$ & - & - & + & + \\
\hline $\mathrm{Na}^{+}$requirement & + & + & - & + \\
\hline Salt growth range $(\% \mathrm{w} / \mathrm{v})$ & $0 \cdot 5-15$ & $0 \cdot 5-20$ & $0-20$ & $0 \cdot 5-20$ \\
\hline Optimum salt concentration $(\% \mathrm{w} / \mathrm{v})$ & 5 & $3-6$ & ND & ND \\
\hline $\mathrm{NO}_{3}^{-}$to $\mathrm{NO}_{2}^{-}$ & - & - & + & - \\
\hline Acid from glucose & - & - & + & + \\
\hline Growth on glucose $e^{*}$ & - & - & + & + \\
\hline Indole & - & - & + & + \\
\hline ONPG & + & - & + & + \\
\hline Urease & - & + & - & + \\
\hline Phosphatase & + & + & + & - \\
\hline Gluconate oxidation & - & + & ND & ND \\
\hline \multicolumn{5}{|l|}{ Fatty acid content $(\%) \dagger$} \\
\hline Major fatty acids & $\begin{array}{c}18: 1 \omega 7 c(68 \cdot 9) \\
16: 0(4 \cdot 3) ; \\
18: 0(3 \cdot 4)\end{array}$ & $\begin{array}{c}18: 1 \omega 7 c(78 \cdot 0) ; \\
16: 0(12 \cdot 4) ; \\
18: 0(2 \cdot 0) ; \\
16: 1 \omega 7 c(1 \cdot 3)\end{array}$ & $\begin{array}{c}18: 1 \\
\text { (not quantified) }\end{array}$ & $\begin{array}{c}18: 1 \\
\text { (not quantified) }\end{array}$ \\
\hline 3-OH fatty acids & $10: 0(5 \cdot 0)$ & $12: 1(2 \cdot 3)$ & - & - \\
\hline Methyl fatty acids & - & $\begin{array}{c}\text { 11-methyl } \\
18: 1 \omega 7 c(1 \cdot 9)\end{array}$ & - & - \\
\hline Cyclo-substituted fatty acids & $\begin{array}{l}19: 0 \text { cyclo } \\
\omega 8 c(12 \cdot 8)\end{array}$ & $\begin{array}{l}19: 0 \text { cyclo } \\
\omega 8 c(2 \cdot 3)\end{array}$ & - & - \\
\hline Unidentified fatty acids & $4 \cdot 870 \mathrm{RT}(2 \cdot 3)$ & - & - & - \\
\hline DNA G $+C$ content $(\mathrm{mol} \%)$ & $64 \cdot 2$ & $64 \cdot 5$ & $64 \cdot 4$ & $59 \cdot 7$ \\
\hline
\end{tabular}

${ }^{\star}$ Growth on minimum medium.

$\dagger$ Only percentages higher than $1 \%$ are shown. 
The phenotypic characteristics and DNA G $+\mathrm{C}$ content are given in the species description. Phenotypic features that distinguish between strain $\mathrm{B} 33^{\mathrm{T}}$, S. mucosus and the two species of Roseivivax are available in Table 1 , where it can be seen that strain $\mathrm{B} 33^{\mathrm{T}}$ is phenotypically most closely related to $S$. mucosus. Both species are Gram-negative, non-motile, moderately halophilic rods. They are chemoheterotrophic, strictly aerobic and produce EPS. They do not produce bacteriochlorophyll $a$. They do not produce acids from sugars and have low nutritional versatility as they cannot grow with any of the carbohydrates, alcohols, organic acids or amino acids tested as sole sources of carbon and energy. For optimum growth strain $\mathrm{B} 33^{\mathrm{T}}$ requires yeast extract $(0.3 \% \mathrm{w} / \mathrm{v})$, malt extract $(0.3 \% \mathrm{w} / \mathrm{v})$ and proteose peptone $(0.5 \% \mathrm{w} / \mathrm{v})$ together with $\mathrm{Na}^{+}(0.66 \mathrm{M}), \mathrm{Mg}^{2+}(0 \cdot 1 \mathrm{M})$ and $\mathrm{K}^{+}(0 \cdot 01 \mathrm{M})$, and thus it flourishes in an MY complex medium (Moraine \& Rogovin, 1966) supplemented with $5 \% \mathrm{w} / \mathrm{v}$ sea salts. The most important phenotypic tests distinguishing between Palleronia marisminoris $\mathrm{B} 33^{\mathrm{T}}$ and S. mucosus are pigment production, a negative reaction for oxidase, urease and gluconate oxidation, positive reaction for ONPG and an inability to grow with $\mathrm{NaCl}$ alone. The DNA $\mathrm{G}+\mathrm{C}$ content of strain $\mathrm{B}-33^{\mathrm{T}}(64 \cdot 2 \mathrm{~mol} \%)$ is very similar to those of $S$. mucosus and R. halodurans (64.5 and $64 \cdot 4 \mathrm{~mol} \%$, respectively).

Fatty acids and quinones were identified by high-resolution GLC and HPLC respectively at Deutsche Sammlung von Mikroorganismen und Zellkulturen $\mathrm{GmbH}$ (Table 1). Strain $\mathrm{B} 33^{\mathrm{T}}$ contains a large quantity of cis-11 octadecenoic acid $(18: 1 \omega 7 c)(68.9 \%)$ together with $19: 0$ cyclo $\omega 8 c$, 3-hydroxy 10:0, 16:0 and 18:0 (12.8, 5, 4.2 and $3 \cdot 4 \%$ respectively). It also has $2 \cdot 3 \%$ of an unknown component at a retention time of $4 \cdot 870 \mathrm{~min}$. The presence of $18: 1 \omega 7 \mathrm{c}$ as the predominant fatty acid is a feature characteristic of taxa within the 'Alphaproteobacteria'. Nevertheless, the cyclo-substituted fatty acid (19:0 cyclo $\omega 8 c)$ is not widely present in the family 'Rhodobacteraceae'; though it has been described in lesser quantities $(2 \cdot 2 \%)$ in $S$. mucosus. The only respiratory lipoquinone detected was ubiquinone- 10 . The presence of ubiquinone- 10 as the dominant respiratory lipoquinone is characteristic of members of the 'Alphaproteobacteria'.

The transmission electron micrograph (Fig. 1), prepared using the methods described by Bouchotroch et al. (2001), shows the cell morphology of strain $\mathrm{B} 33^{\mathrm{T}}$. Thin sections reveal a typical Gram-negative cell-envelope profile; the cell contains poly- $\beta$-hydroxyalkanoate (PHA) granules. EPS appears in the external medium.

We determined the almost-complete $16 \mathrm{~S}$ rRNA gene sequence of strain $\mathrm{B} 33^{\mathrm{T}}$ (1351 bp) corresponding to positions 46 to 1445 of the E. coli $16 \mathrm{~S}$ rRNA gene using standard protocols (Saiki et al., 1988). The forward primer was $16 \mathrm{~F} 27$ ( $5^{\prime}$-AGAGTTTGATCMTGGCTCAG-3'), annealing at positions 8-27, and the reverse primer was 16R1488 (5'CGGTTACCTTGTTAGGACTTCACC- $3^{\prime}$ ), annealing at the complement of positions 1511-1488 (E. coli numbering

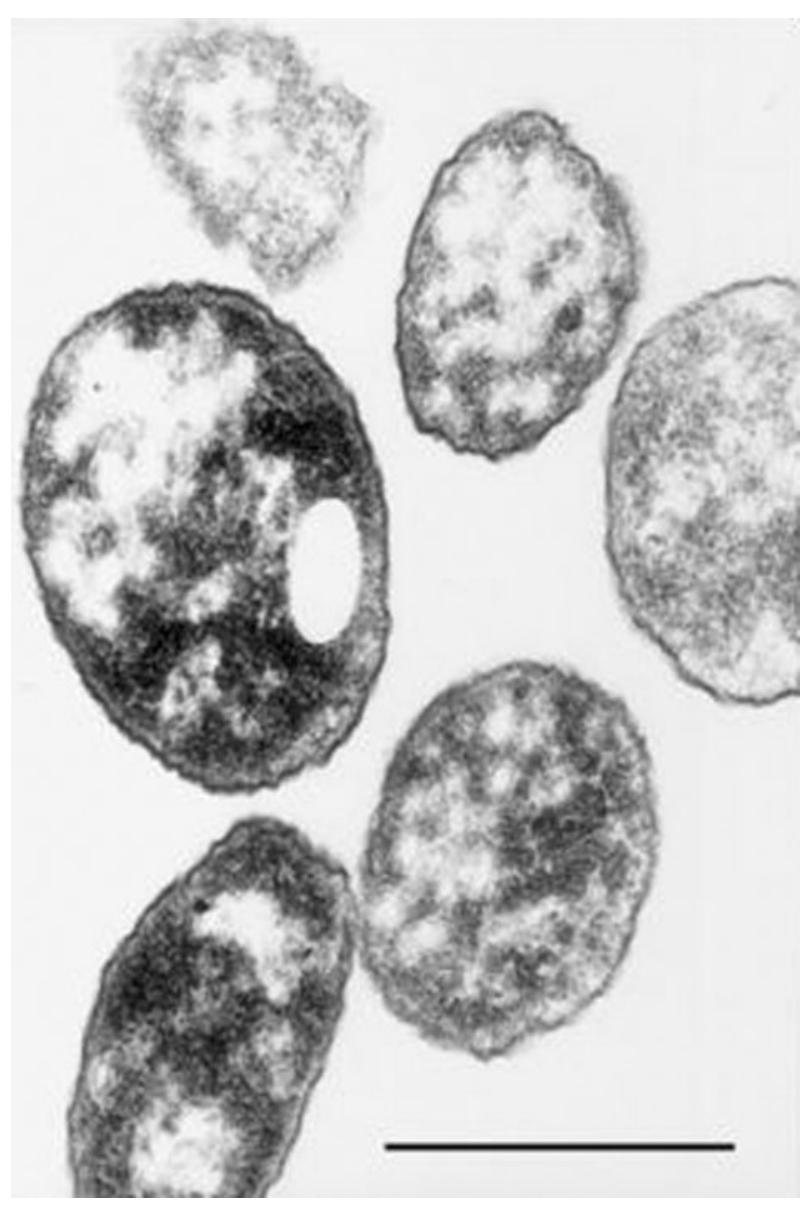

Fig. 1. Transmission electron micrograph of Palleronia marisminoris $\mathrm{B}_{3} 3^{\top}$ cells stained with ruthenium red. Bar, $1 \mu \mathrm{m}$.

according to Brosius et al., 1978). The PCR products were purified using the Qiaquick spin-gel extraction kit (Qiagen). Direct sequence determinations of PCR-amplified DNAs were carried out with the ABI PRISM dye-terminator, cyclesequencing, ready-reaction kit (Perkin-Elmer) and an $\mathrm{ABI}$ PRISM 377 sequencer (Perkin-Elmer) according to the manufacturer's instructions. The sequences obtained were compared with reference 16S rRNA gene sequences available in the GenBank/EMBL/DDBJ databases obtained from the National Center of Biotechnology Information database using the BLAST search. Phylogenetic analysis was made using the software MEGA version 3.0 (Kumar et al., 2004) after multiple alignments of data by CLUSTAL_X (Thompson et al., 1997). Distances and clustering were determined with the neighbour-joining and maximum-parsimony methods. The stability of the clusters was ascertained by performing a bootstrap analysis (1000 replications). Our phylogenetic analysis with the neighbour-joining method included, along with the sequence of $\mathrm{B} 33^{\mathrm{T}}$, some representatives of the family 'Rhodobacteraceae' (Fig. 2 and Supplementary Fig. S1 in IJSEM Online). The maximum-parsimony algorithm gave a similar result (data not shown). Strain $\mathrm{B} 33^{\mathrm{T}}$ showed $92 \cdot 2 \%$ 16S rRNA gene sequence similarity with $S$. mucosus. Other 


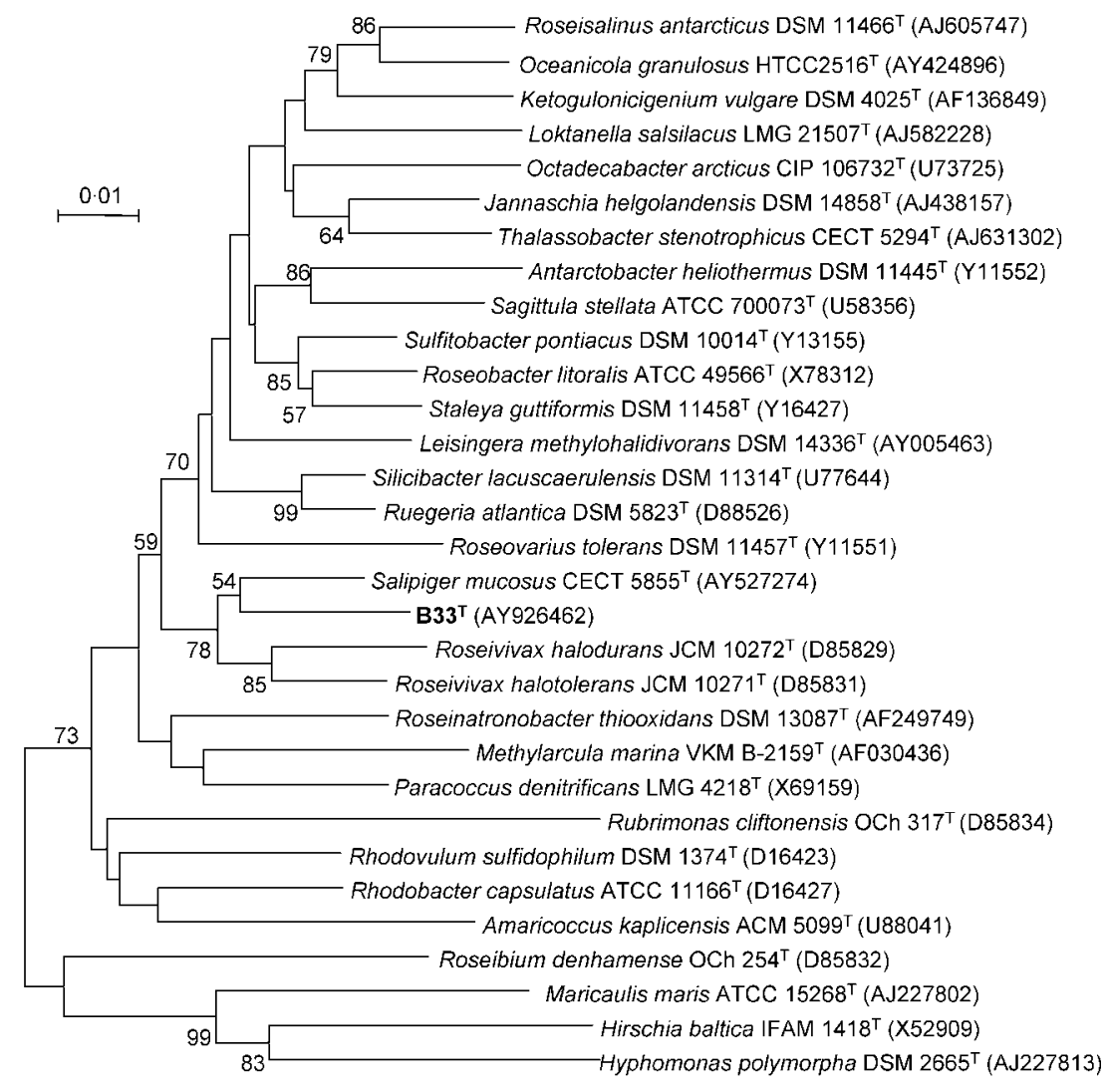

Fig. 2. Phylogenetic relationships between Palleronia marisminoris $\mathrm{B}^{3} 3^{\top}$ and other genera of the family 'Rhodobacteraceae'. The tree was constructed using the neighbourjoining algorithm. Only bootstrap values above $50 \%$ are shown (1000 replications). Bar, $1 \%$ estimated sequence divergence. phylogenetically close species were Roseivivax halodurans and Roseivivax halotolerans, with which it showed $88 \cdot 2$ and $88.0 \%$ sequence similarity, respectively. Strain $\mathrm{B} 33^{\mathrm{T}}$ is in the same clade as Roseivivax and Salipiger, belonging to the $\alpha-3$ group of the 'Alphaproteobacteria' within the family 'Rhodobacteraceae' (Garrity et al., 2001). Roseivivax is taxonomically related to the Roseobacter clade, a group of genera of the family 'Rhodobacteraceae' (Allgaier et al., 2003), which make up the most abundant population in marine habitats (González \& Moran, 1997).

DNA-DNA hybridization was done according to Lind and Ursing's method (Lind \& Ursing, 1986) with the modifications of Ziemke et al. (1998) and Bouchotroch et al. (2001). DNA-DNA hybridization values of $B 33^{\mathrm{T}}$ with the most phylogenetically related species, $R$. halodurans, $R$. halotolerans and S. mucosus, are $22,27 \cdot 7$ and $29 \cdot 7 \%$, respectively.

Thus, on the basis of phylogenetic evidence, DNA-DNA hybridization values, fatty-acid profiles, quinones, differences in phenotypic characteristics and its inability to synthesize bacteriochlorophyll $a$, we are of the opinion that strain $\mathrm{B} 33^{\mathrm{T}}$ should be recognized as the representative species of a novel genus, for which we propose the names Palleronia and Palleronia marisminoris.

\section{Description of Palleronia gen. nov.}

Palleronia (Pall.er.o'nia. N.L. sb. f. Palleronia in honour of Professor Norberto Palleroni, a pioneer in the use of molecular identification techniques in prokaryote taxonomy).

Gram-negative, short, non-motile rods, $2-2 \cdot 5 \mu \mathrm{m}$ long by $0 \cdot 75-1 \mu \mathrm{m}$ wide. Neither flagella nor endospores are present. Bacteriochlorophyll $a$ is absent. Metabolism is chemoheterotrophic and aerobic, the cells being unable to grow under anaerobic conditions either by fermentation, nitrate or fumarate reduction or photoheterotrophy. PHA and catalase are present. Oxidase test is negative. Colonies contain pink pigment. The bacteria cannot produce acids from sugars and have low nutritional and biochemical versatility. They are strictly halophilic, requiring $\mathrm{Na}^{+}$, $\mathrm{Mg}^{2+}$ and $\mathrm{K}^{+}$for growth. The principal cellular fatty acids are $18: 1 \omega 7 c$ and 19:0 cyclo $\omega 8 c$. They have ubiquinone with ten isoprene units. The type species is Palleronia marisminoris.

\section{Description of Palleronia marisminoris sp. nov.}

Palleronia marisminoris (ma' ris.min.or.is. L. sb. n. gen. maris of the sea; L. adj. n. gen. minoris smaller; L. adj. marisminoris of the smaller sea, i.e. from el Mar Menor, a shallow area of sea highly sheltered from the Mediterranean sea on the south-eastern coast of Spain, from whence the type strain was isolated).

In addition to the traits reported for the genus, the species grows on MY solid medium in the form of circular, convex, pink, mucoid colonies. In liquid medium its growth pattern 
is uniform. The cells are encapsulated. It is moderately halophilic, capable of growing in salt concentrations (mixture of sea salts) from 0.5 to $15 \% \mathrm{w} / \mathrm{v}$. Optimum growth occurs at $5 \% \mathrm{w} / \mathrm{v}$ sea salt. It cannot grow with $\mathrm{NaCl}$ as the sole salt. Minimum salt requirements are $0.66 \mathrm{M} \mathrm{Na}^{+}, 0 \cdot 1 \mathrm{M} \mathrm{Mg}^{2+}$ and $0.01 \mathrm{M} \mathrm{K}^{+}$. It grows within the temperature range of 20 to $37^{\circ} \mathrm{C}$ and at $\mathrm{pH}$ values of between 5 and 10. It produces $\mathrm{H}_{2} \mathrm{~S}$ from L-cysteine. Selenite reduction and phosphatase tests are positive. Tween 20 is hydrolysed. It does not produce acids from the following sugars and related compounds: adonitol, D-cellobiose, D-fructose, D-galactose, D-glucose, myo-inositol, lactose, maltose, D-mannitol, D-mannose, D-melezitose, L-rhamnose, sucrose, D-salicin, D-sorbitol, sorbose and D-trehalose. ONPG is positive. O/F, indole, methyl-red, Voges-Proskauer and gluconate oxidation are negative. Phenylalanine deaminase is not produced. Urea, tyrosine, Tween 80 , starch, aesculin, gelatin, DNA, lecithin and casein are not hydrolysed. Growth on either MacConkey or cetrimide agar is inviable. Blood is not lysed. Neither nitrate nor nitrite is reduced. The following compounds are not acceptable as sole carbon and energy sources: L-arabinose, D-cellobiose, aesculin, D-fructose, glucose, galactose, lactose, maltose, D-mannose, D-salicin, trehalose, acetate, citrate, formate, fumarate, gluconate, lactate, malonate, propionate, succinate, adonitol, ethanol, glycerol, inositol, mannitol and sorbose. The following compounds are not used as sole carbon, nitrogen and energy sources: L-alanine, L-cysteine, D-histidine, isoleucine, L-lysine, L-methionine, L-serine, tryptophan and L-valine. It is susceptible to $(\mu \mathrm{g})$ amoxicillin (25), ampicillin (10), carbenicillin (100), cefotaxime (30), cefoxitin (30), chloramphenicol (30), erythromycin (15), kanamycin (30), streptomycin (10), nitrofurantoin (300), rifampicin (30) and tobramycin (10) and is resistant to nalidixic acid (30), polymyxin B (300) sulfonamide (250) and trimethoprim/ sulfamethoxazole $(1 \cdot 25 / 23 \cdot 7)$. The major fatty acids are: $18: 1 \omega 7 c(68 \cdot 9 \%), 19: 0$ cyclo $\omega 8 c(12 \cdot 8 \%)$, 3-hydroxy $10: 0(5 \%), 16: 0(4 \cdot 2 \%), 18: 0(3 \cdot 4 \%)$. DNA G +C content is $64 \cdot 2 \mathrm{~mol} \%$ ( $T_{\mathrm{m}}$ method).

The type strain, strain $B 33^{\mathrm{T}} \quad\left(=\mathrm{CECT} \quad 7066^{\mathrm{T}}=\mathrm{LMG}\right.$ $22959^{\mathrm{T}}$ ), was isolated from a hypersaline soil bordering a solar saltern in Marchamalo (Murcia, south-eastern Spain).

\section{Acknowledgements}

This research was supported by grants from the Dirección General de Investigación Científica y Técnica (BOS2003-00498) and from the Plan Andaluz de Investigación, Spain. The authors are grateful to their colleague Dr J. Trout for revising the English text and for his help with the nomenclature and to Concepción Fernández and David Porcel for their expertise in the electron microscope studies.

\section{References}

Allgaier, M., Uphoff, H., Felske, A. \& Wagner-Döbler, I. (2003). Aerobic anoxygenic photosynthesis in Roseobacter clade bacteria from diverse marine habitats. Appl Environ Microbiol 69, 5051-5059.
Bouchotroch, S., Quesada, E., del Moral, A., Llamas, I. \& Béjar, V. (2001). Halomonas maura sp. nov., a novel moderately halophilic, exopolysaccharide-producing bacterium. Int J Syst Evol Microbiol 51, 1625-1632.

Brosius, J., Palmer, M. L., Kennedy, P. J. \& Noller, H. F. (1978). Complete nucleotide sequence of a $16 \mathrm{~S}$ ribosomal RNA gene from Escherichia coli. Proc Natl Acad Sci U S A 75, 4801-4805.

Cohen-Bazire, G., Sistrom, W. R. \& Stanier, R. Y. (1957). Kinetic studies of pigment synthesis by non-sulfur purple bacteria. J Cell Comp Physiol 49, 25-68.

Ferragut, C. \& Leclerc, H. (1976). Etude comparative des methodes de determination du $T_{\mathrm{m}}$ de l'ADN bacterien. Ann Microbiol 127, 223-235 (in French).

Garrity, G. M. \& Holt, J. G. (2001). The road map to the Manual. In Bergey's Manual of Systematic Bacteriology, 2nd edn, vol. 1, pp. 119-166. Edited by D. R. Boone, R. W. Castenholz \& G. M. Garrity. New York: Springer.

González, J. M. \& Moran, M. A. (1997). Numerical dominance of a group of marine bacteria in the alpha-subclass of the class Proteobacteria in coastal seawater. Appl Environ Microbiol 63, 4237-4242.

Kumar, S., Tamura, K. \& Nei, M. (2004). MEGA3: integrated software for molecular evolutionary genetics analysis and sequence alignment. Brief Bioinform 5, 150-163.

Kushner, D. J. \& Kamekura, M. (1988). Physiology of halophilic bacteria. In Halophilic Bacteria, pp. 109-138. Edited by F. RodríguezValera. Boca Raton, FL: CRC Press.

Lind, E. \& Ursing, J. (1986). Clinical strains of Enterobacter agglomerans (synonyms: Erwinia herbicola, Erwinia milletiae) identified by DNA-DNA hybridization. Acta Pathol Microbiol Immunol Scand [B] 94, 205-213.

Marmur, J. (1961). A procedure for the isolation of deoxyribonucleic acid from microorganisms. J Mol Biol 3, 208-212.

Marmur, J. \& Doty, P. (1962). Determination of the base composition of deoxyribonucleic acid from its thermal denaturation temperature. J Mol Biol 5, 109-118.

Martínez-Cánovas, M. J., Béjar, V., Martínez-Checa, F. \& Quesada, E. (2004a). Halomonas anticariensis sp. nov., from Fuente de Piedra, a saline-wetland, wildfowl reserve in Málaga, southern Spain. Int J Syst Evol Microbiol 54, 1329-1332.

Martínez-Cánovas, M. J., Béjar, V., Martínez-Checa, F., Páez, R. \& Quesada, E. (2004b). Idiomarina fontislapidosi sp. nov. and Idiomarina ramblicola sp. nov. isolated from inland hypersaline habitats in Spain. Int J Syst Evol Microbiol 54, 1793-1797.

Martínez-Cánovas, M. J., Quesada, E., Llamas, I. \& Béjar, V. (2004c). Halomonas ventosae sp. nov., a moderately halophilic, denitrifying, exopolysaccharide-producing bacterium. Int J Syst Evol Microbiol 54, 733-737.

Martínez-Cánovas, M. J., Quesada, E., Martínez-Checa, F. \& Béjar, V. (2004d). A taxonomic study to establish the relationship between exopolysaccharide-producing bacterial strains living in diverse hypersaline habitats. Curr Microbiol 48, 348-353.

Martínez-Cánovas, M. J., Quesada, E., Martínez-Checa, F., del Moral, A. \& Béjar, V. (2004e). Salipiger mucescens gen. nov., sp. nov., a moderately halophilic, exopolysaccharide-producing bacterium isolated from hypersaline soil, belonging to the $\alpha$-Proteobacteria. Int J Syst Evol Microbiol 54, 1735-1740.

Martínez-Checa, F., Béjar, V., Martínez-Cánovas, M. J., Llamas, I. \& Quesada, E. (2005a). Halomonas almeriensis sp. nov., a moderately halophilic, exopolysaccharide-producing bacterium from Cabo de Gata, Almería, south-east Spain. Int J Syst Evol Microbiol 55, 2007-2011. 
Martínez-Checa, F., Béjar, V., Llamas, l., del Moral, A. \& Quesada, E. (2005b). Alteromonas hispanica sp. nov., a polyunsaturated-fattyacid-producing, halophilic bacterium isolated from Fuente de Piedra, southern Spain. Int J Syst Evol Microbiol 55, 2385-2390.

Mata, J. A., Martínez-Cánovas, M. J., Quesada, E. \& Béjar, V. (2002). A detailed phenotypic characterisation of the type strains of Halomonas species. Syst Appl Microbiol 25, 360-375.

Moraine, R. A. \& Rogovin, P. (1966). Kinetics of polysaccharide B-1459 fermentation. Biotechnol Bioeng 8, 511-524.

Nishimura, Y., Muroga, Y., Saito, S., Shiba, T., Takamiya, K. \& Shioi, Y. (1994). DNA relatedness and chemotaxonomic feature of aerobic bacteriochlorophyll-containing bacteria isolated from coasts of Australia. J Gen Appl Microbiol 40, 287-296.

Owen, R. J. \& Hill, L. R. (1979). The estimation of base compositions, base pairing and genome size of bacterial deoxyribonucleic acids. In Identification Methods for Microbiologists, 2nd edn, pp. 277-296. Edited by F. A. Skinner \& D. W. Lovelock. London: Academic Press.

Owen, R. J. \& Pitcher, D. (1985). Current methods for estimating DNA composition and levels of DNA-DNA hybridization. In Chemical Methods in Bacterial Systematics, pp. 67-93. Edited by M. Goodfellow \& D. E. Minnikin. London: Academic Press.

Quesada, E., Ventosa, A., Rodríguez-Valera, F., Megias, L. \& Ramos-Cormenzana, A. (1983). Numerical taxonomy of moderately halophilic Gram-negative bacteria from hypersaline soils. J Gen Microbiol 129, 2649-2657.

Quesada, E., Valderrama, M. J., Béjar, V., Ventosa, A., Gutierrez, M. C., Ruiz-Berraquero, F. \& Ramos-Cormenzana, A. (1990). Volcaniella eurihalina gen. nov., sp. nov., a moderately halophilic non-motile Gram-negative rod. Int J Syst Bacteriol 40, 261-267.

Quesada, E., Béjar, V., Ferrer, M. R. \& 8 other authors (2004). Moderately halophilic, exopolysaccharide-producing bacteria. In
Halophilic Microorganisms, pp. 297-314. Edited by A. Ventosa. Heidelberg: Springer.

Rodríguez-Valera, F., Ruiz-Berraquero, F. \& Ramos-Cormenzana, A. (1981). Characteristics of the heterotrophic bacterial populations in hypersaline environments of different salt concentrations. Microb Ecol 7, 235-243.

Saiki, R. K., Gelfand, D. H., Stoffel, S., Scharf, S. J., Higuchi, R., Horn, G. T., Mullis, K. B. \& Erlich, H. A. (1988). Primer-directed enzymatic amplification of DNA with thermostable DNA polymerase. Science 239, 487-491.

Sutherland, I. W. (1990). Biotechnology of Microbial Exopolysaccharides. Cambridge: Cambridge University Press.

Suzuki, T., Muroga, Y., Takahama, M. \& Nishimura, Y. (1999). Roseivivax halodurans gen. nov., sp. nov., and Roseivivax halotolerans sp. nov., aerobic bacteriochlorophyll-containing bacteria isolated from a saline lake. Int J Syst Bacteriol 49, 629-634.

Thompson, J. D., Gibson, T. J., Plewniak, K., Jeanmougin, F. \& Higgins, D. G. (1997). The CLUSTAL_X windows interface: flexible strategies for multiple sequence alignment aided by quality analysis tools. Nucleic Acids Res 25, 4876-4882.

Ventosa, A., Quesada, E., Rodríguez-Valera, F., Ruiz-Berraquero, F. \& Ramos-Cormenzana, A. (1982). Numerical taxonomy of moderately halophilic Gram-negative rods. J Gen Microbiol 128, 1959-1968.

Ventosa, A., Nieto, J. J. \& Oren, A. (1998). Biology of moderately halophilic aerobic bacteria. Microbiol Mol Biol Rev 62, 504-544.

Ziemke, F., Hofle, M. G., Lalucat, J. \& Rosselló-Mora, R. (1998). Reclassification of Shewanella putrefaciens Owen's genomic group II as Shewanella baltica sp. nov. Int J Syst Bacteriol 48, 179-186. 